Edukids 15 (1), 2018

EDUKIDS: Jurnal Pertumbuhan, Perkembangan, dan Pendidikan Anak Usia Dini

Jln. Dr. Setiabudhi No. 229 Kota Bandung 40154. e-mail: edukid@ upi.edu

website: http://ejournal.upi.edu/index.php/edukid

\title{
KECEPATAN MENAMBAH KOSAKATA BAHASA SUNDA ANAK MELALUI KEGIATAN NGAWIH PUPUH SUNDA
}

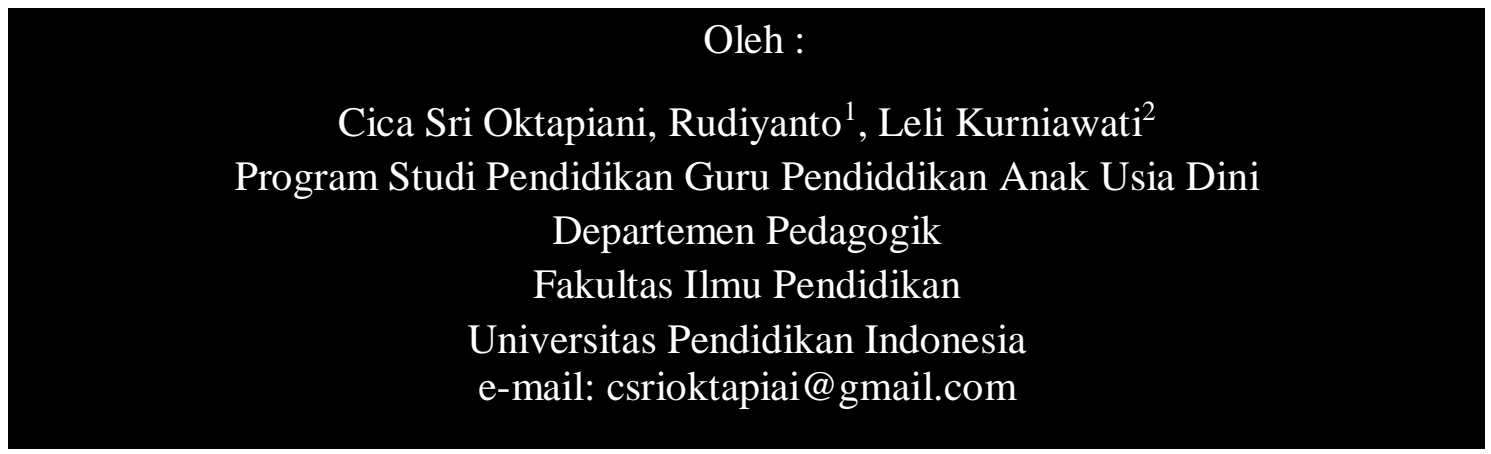

Abstrak: Penelitian ini dilatar belakangi oleh permasalahan yang muncul pada anakanak Kelompok B Kelas Ubur-Ubur TK Labortorium Percontohan UPI, yaitu masih rendahnya kosakata Bahasa Sunda anak yang terlihat dari hasil observasi bahwa $90 \%$ anak berada pada kategori kurang dan $10 \%$ berada pada kategori cukup. Karena pentingnya kosakata Bahasa Sunda anak dalam kehidupan sehari-hari maka diperlukan upaya untuk menambah kosakata bahasa sunda anak, salah satunya melalui kegiatan ngawih pupuh sunda. Tujuan dari penelitian ini adalah untuk mengetahui apakah kegiatan ngawih pupuh sunda dapat menambah kosakata Bahasa Sunda anak pada Kelompok B Kelas Ubur-Ubur Tk Labortorium Percontohan UPI. Metode penelitian yag digunakan dalam penelitian ini adalah metode Penelitian Tindakan Kelas (PTK) kolaboratif anatara peneliti dan guru kelas. Penelitian ini mengadaptasi desain Kemmis dan McTaggart. Lokasi penelitian di laksanakan di Tk Laboratorium Percontoha UPI dengan partisipan sebayak 10 anak. Hasil penelitian yang di dapatkan pada kondisi awal menambah kosakata bahasa sunda menunjukan sebagian besar anak berada pada kategori kurang (K). pada akhir siklus I terlihat penambahan kosakata sebagan besar anak mulai berada pada kategori cukup (C). kemudian peningkatan yang signifikan muncul pada akhir siklus II yaitu sebagia besar anak berada pada kategori baik (B). kegiatan ngawih pupuh sunda ternyata dapat menambah kosakata bahasa sunda anak khususnya Kelompok B Kelas Ubur-Ubur Tk Labortorium Percontohan UPI.

Kata Kunci : Kosakata Bahasa Sunda, Pupuh

\footnotetext{
1 Penulis Peanggung Jawab

2 Penulis Peanggung Jawab
} 


\section{PENDAHULUAN}

Pendidikan anak usia dini merupakan pendidikan yang sangat fundamental atau mendasar dalam perkembangan dan terbentuknya dasardasar pengetahuan sikap dan keterampilan anak. salah satu perkembangan anak serta keterampilan yang di kembangkan di pendidikan anak usia dini adalah perkembangan dan keterampilan bahasa anak. Bahasa merupakan salah satu sarana berkomunikasi dengan orang lain. Melalui bahasa, anak dapat menyatakan pemikiran, perasaan dalam bentuk tulisan, lisan dan isyarat atau gerak. Suhartono (2005:12-13) menyatakan bahwa kemampuan menggunakan bahasa pada anak, akan memudahkannya bergaul dan menyesuaikan diri dengan lingkungannya, karena bahasa berperan sebagai : sarana untuk berfikir dan bernalar, alat untuk penerus dan pengembang kebudayaan serta penting dalam mempersatukan anggota keluarga. Sejalan dengan pernyataan Suhartono, bahwa bahasa merupakan pengembang kebudayaan, maka tentunya menjadi suatu hal yang sangat penting bahwa pengembangan bahasa pada anak di terapkan. Pengembangan kebudayaan yang berimplikasi dengan bahasa adalah penggunaan bahasa ibu atau bahasa daerah. Bahasa ibu merupakan bahasa kedua yang anak dapatkan setelah bahasa indonesia. Bahasa daerah adalah suatu bahasa yang dituturkan di wilayah dalam sebuah Negara kebangsaan.

Dewasa ini, pengenalan Bahasa Sunda pada anak usia dini sudah sangat jarang dipergunakan. Walapun penggunaan bahasa sunda difasilitasi oleh program "Rebo nyunda", namun tetap saja dalam praktek dilapangan masih banyak anak usia dini yang sama sekali tidak dapat berbahasa Sunda. Hal ini disebabkan oleh kegagalan transmisi bahasa dalam keluarga, selain itu juga tejadinya pergeseran dimana bahasa ibu yang awalnya merupakan bahasa kedua menjadi bahasa ketiga dst. Dalam masyarakat yang multi bahasa persaingan bahasa merupakan fenomena yang sering terjadi sebagai akibat kontak bahasa (sobarna, cece 2007). Merosotnya jumlah penutur bahasa karena adanya persaingan bahasa (desakan Bahasa Indonesia dan Bahasa Asing) dan semakin kurangnya loyalitas penutur terhadap pemakaian bahasa daerah sebagai bahasa ibu (Yadnya, 2003: 3). Karena fenomena ini hampir di seluruh Indonesia pengunaan bahasa daerah khususanya bahasa sunda sudah jarang diperkenalkan dan digunakan. Akibatnya, bahasa Sunda kurang mampu mengimbangi dominasi bahasa nasional atau asing. Adapun penelitian yang dilakukan oleh Yetti Kurniawati (2009) bahwa penguasaan kosakata bahasa sunda anak-anak Tk di Kabupaten Bandung yang hampir mayoritas bersuku sunda berada pada kategori sedang, yaitu sekitar 57\% dapat menyebutkan anggota tubuh dalam bahasa sunda, sedangkan sisanya $47 \%$ tidak menguasai sepuluh kata yang diujikan.

Beberapa faktor penyebab kurangnya kemampuan anak dalam berbahasa sunda dilihat dari fenomena yang terjadi di lapangan adalah sebagai berikut : 1 . Sudah tidak dipakainya bahasa sunda sebagai sarana komunikasi baik dengan orangtua maupun pendidik, sehingga anak merasa asing dengan bahasa ibu. 2. Pergeseran kedudukan bahasa pertama dan kedua, dimana bahasa ibu sekarang dianggap bahasa kedua. 3. Penggunaan bahasa sunda di program prasekolah jarang digunakan, karena bahasa daerah masih dianggap mutan lokal seingga implementasi hanya di dasarkan pada keharusan memenuhi kurikulum, bukan berdasarkan kebutuhan anak untuk mengenal budaya daerahnya. 4 . Tuntutan global, dimana banyak sekolah melakukan program bilingual (penggunaan dua bahasa) yang kebanyakan menggunakan Bahasa Indonesia dan bahasa asing saja. 5. Pembelajaran bahasa sunda khususnya di program anak usia dini masih terbatas oleh penyampaian guru 
yang kurang memunculkan minat anak, kurangnya media pembelajaran serta metode-metode yang bersifat menyenangkan bagi anak.

Dalam rangka melestarikan bahasa daerah khususnya bahsa sunda pemerintah memasukan bahasa sunda kedalam materi dalam kurikulum dan kebijakan pendidikan melalui Dinas Provinsi Jawa Barat dengan mengembangkan Standar Kompetensi Dan Kompetensi Dasar (SKKD) Mata Pelajaran Bahasa Sunda dan Sastra Sunda disusun berdasarkan Peraturan Daerah Provinsi Jawa Barat N0. 5 Tahun 2003 Tentang Pemeliharaan Bahasa, Sastra dan Aksara Daerah, yang menetapkan Bahasa Daerah, antara lain Bahasa Sunda, harus di ajarkan mulai dari Taman Kanak-Kanak (TK) sampai Sekolah Menengah Atas (SMA) di Jawa Barat.

Berdasarkan hasil observasi di TK Laboratorium Percontohan UPI Pada Kelompok B kosakata bahasa sunda anak masih sangatlah kurang beragam. Hal ini dapat terlihat dari data hasil observasi dilapangan dimana dari 50 item pertanyaan yang diajukan hanya $10 \%$ anak mendapatkan skor cukup. Hal ini juga terlihat dari kegiatan pembelajaran seharihari yang tidak memunculkan bahasa sunda pada bahasa pengantar pembelajaran. Bahasa sunda sendiri dipakai sebagai pembiasaan setiap hari pada saat menyapa saja. Guru dan anak terlihat jarang sekali menggunaka bahasa sunda dalam percakapannya. Seperti pada Rebo nyunda bahasa pengatar tetap menggunakan bahasa indonesia. Selain itu anak di rumah terbiasa menggunaka Bahasa Indonesia begitupun disekolah. Sehingga tidak ada kesempatan bagi anak mengetahui dan menggunakan bahasa sunda sebagai bahasa daerahnya.

Metode yang dapat digunakan dalam pembelajaran bahasa sunda di pendidikan anak usia dini adalah pupuh. Pupuh merupakan karya sastra berbentuk puisi yang termasuk bagian dari sastra Sunda. Penggunaan pupuh biasanya hanya digunakan di sekolah dasar, menengah hingga sekolah menengah atas saja sebagai salah satu muatan lokal. Menutut Lili Suparli (2017) bahwa "Penggunaan pupuh untuk anak usia dini, bukan bagaimana anak memahami esensi dari pupuh itu sendiri, bukan bagaimana anak terampil dalam menyanyikan pupuh atau ngawih, namun bagaimana anak mampu memahami mengenal bahasa sunda dengan metode bernyanyi pupuh". Selain itu juga menurut Lili Suparli (2017) “ Pupuh yang proporsioanal bagi anak adalah merubah lirik atau syarir lagu pupuh menjadi syair yang mudah di cerna oleh pemahaman anak sebagai salah satu media belajar". Pupuh merupakan lirik atau syair yang di lantukan dengan nada-nada sehingga membentuk pola nyanyian. Pupuh juga termasuk kedalam seni suara sunda atau tembang sunda. Tembang sunda inilah yang kita kenal dengan salah satu ragam metode bernyanyi.

Menurut Hendarsyah (2017) manfaat pupuh bagi anak usia dini berbeda dengan manfaat pupuh yang diperuntukan untuk anak sekolah dasar, menengah pertama dan menengah atas. Manfaat pupuh bagi anak usia dini yaitu : sebagai salah satu media anak mengenal kosa kata bahasa sunda dari rumpaka pupuh, kemudian berangkat dari kosakata anak akan belajar memahami makna atau nilai pesan yang terkandung dalam pupuh tersebut. Selain itu Lili Suparli (2017) menuturkan bahwa pupuh sendiri memiliki manfaat bagi anak sebagai media anak belajar etika dan nilainilai moral. Pupuh bagi anak usia dini ditujukan bukan mengasah vokal anak secara intens. Melainkan untuk menstimulasi bakat anak melalui pupuh itu sendiri. Dengan penggunaan pupuh menjadi dasar awal anak belajar tembang sunda, kemudian pengenalan syair menggunakan bahasa sunda dari rumpaka pupuh dapat mengasah kemampuan anak dalam membuat syair.

Berdasarkan kajian dari latar belakang masalah di atas, maka penulis membatasi masalah ini sehingga tidak 
meluas dengan merumuskan beberapa pertanyaan penelitian, sebagai berikut :

1. Bagaimana kondisi objektif kosakata Bahasa Sunda anak usia dini Kelompok B Kelas Ubur-ubur di TK Laboratorium Percontohan UPI?

2. Bagaimana pelaksanaan kegiatan ngawih pupuh sunda dalam kecepatan menambah kosakata Bahasa Sunda pada anak Kelompok B ?

3. Bagaimana hasil kecepatan menambah kosakata Bahasa Sunda setelah pelaksanaan kegiatan ngawih pupuh sunda ?

Adapun tujuan dari penelitian ini adalah :

a. Tujuan umum

Penelitian ini bertujuan untuk mengetahui proses kecepatan menambah kosakata bahasa sunda Kelompok B Kelas Ubur-ubur pada anak TK Laboratorium Percontohan UPI melalui kegiatan ngawih pupuh sunda.

b. Tujuan khusus

1) Mengetahui kondisi objektif kosa kata Bahasa Sunda anak usia dini Kelompok B Kelas Ubur-ubur di TK Laboratorium Percontohan UPI

2) Mengetahui pelaksanaan kegiatan ngawih pupuh sunda dalam meningkatkan kosa kata Bahasa Sunda pada anak Kelompok B.

3) Mengetahui kecepatan menambah kosa kata Bahasa Sunda setelah pelaksanaan kegiatan ngawih pupuh sunda.

\section{KAJIAN PUSTAKA}

\section{Kosakata}

Kata merupakan satuan bahasa terkecil yang dapat berdiri sendiri. Menurit Keraf (1980:50) kata sebagai satuan terkecil yang mengandung ide, yang di peroleh apabila sebuah kalimat dibagi atas bagianbagiannya. Kata adalah bentuk bebas yang paling kecil, misalnya dalam bahasa sunda bentuk-bentuk dahar, "makan", ema "Ibu" dsb. Dapat disimpulkan bahwa kata merupakan sekumpulan huruf atau potongan-potongan kalimat yang memiliki arti dan dapat berdiri sendiri.

Menurut Keraf (1987:68) pengertian kosakata adalah perbendaharaan kata, yaitu kata-kata yang segera akan diketahui kembali artinya bila mendengarkan kembali, walaupun jarang atau tidak pernah lagi dipergunakan dalam percakapan atau tulisannya sendiri. Adapun pendapat lain menurut Krismas (2005: 27) kosakata adalah salah satu unsur bahasa yang mengajarkan bentukbentuk kata dari berbagai ranah kebahasaan dalam jumlah yang diperlukan untuk berkomunikasi dengan lancar.

Pendapat lain mengenai kosakata disampaikan oleh Dale dalam Tarigan (1989: 3) secara lebih rinci mengenai kosakata sebagai berikut :

1. Kualitas dan kuantitas penguasaan kosakata seseorang merupakan indeks pribadi yang terbaik bagi perkembangan mentalnya

2. Perkembangan kosakata merupakan perkembangan konseptual

3. Sistematis pengembangan kosakata dipengaruhi oleh usia, jenis kelamin, kemampuan dan status sosial

4. Faktor geografis mempengaruhi perkembangan kosakata

5. Penelaahan kosakata yang efektif hendaknya beranjak dari kata-kata yang sudah diketahui menuju katakata yang belum atau tidak diketahui.

Dari beberapa penjelasan di atas dapat disimpulkan bahwa perbendaharaan kata atau kosa kata anak didapatkan memlaui komunikasi dengan lingkungan sekitar, melalui proses interaksi dan penggunaan dalam konteks keseharian baik dalam proses belajar dikelas, bermain dsb. Belajar bahasa sunda tidak terlepas dari pentingnya penguasaan kosakata. Ketika penguasaan kosakata anak kurang 
memadai maka akan memunculkan kendala dalam keterampilan berbahasa anak sehingga pemahaman mengenai kosakata bahasa sunda akan sulit berkembang.

Penguasaan kosakata dalam pembelajaran tidak dapat dipisahkan. Keberhasilan proses belajar mengajar ditentukan salah satunya oleh penguasaan kosakata yang dimiliki anak. Perkembangan penguasaan kosakata anak berpengaruh pada kemampuan dan keterampilan mengungkapkan ide dan bahasa secara tepat. Perkembangan kosakata mengandung pengertian lebih daripada pemahaman kata-kata baru kedalam perbendaharaan pengalaman.

Jumlah Rata-Rata Kosakata Anak

Menurut Dhien (2015:3.1) anak prasekolah akan meningkatkan kosakata dan tata bahasanya. Sampai di usia 3 tahun anak diharapkan memiliki 900-1000 kata, sedangkan pada usia 6 tahun kosa kata anak akan meningkat menjadi 2600 kata yang berbeda. Seiring bertambahnya usia, anak harus memiliki kosakata yang jauh lebih banyak. Peningkatan kosakata dalam perkembangan bahasa anak di peroleh dari proses pembelajaran. Peningkatan kosakata itu sendiri di dapatkan oleh anak melalui percakapan yang anak lakukan dengan orang tua, teman sebaya dan guru atau orang dewasa lain di sekitarnya.

Pada usia 18 bulan, anak-anak biasanya memiliki kosakata 3 sampai 100 kata, secara bertahap anatara uisa 1,5 sampai 2,5 tahun anak-anak mulai mengkombinasikan kata-kata tunggal untuk menghasilkan dua kata. Kosakata berkembang denga cepat hingga tiga kali lipat dari sekitar 300 kata pada usia 2 tahun menjadi 1.000 kata pada usia 3 tahun. Anak usia 4 tahun mencapai fondasi sintaksis dan strukturbahasa orang dewasa dan pada usia anak 5 tahun, kebanyakan anak juga bisa mengerti da memproduksi konstruksi kalimat yag cukup kompleks dan tidak lazim. (siegler, 1986)

$$
\text { Adapun pendapat Hurlock }
$$

(1978:189) bahwa rata-rata usia 18 bulan jumlah kata ynag digunakan adalah 10, pada usia 24 bulan adlaah 29.1. kosakata anak umur 2 tahun berisi rata-rata 200 sampai 300 kata. Usia 3 tahun rata-rata penggunaan kata sekitar 380-900 kata, kemudian pada usia 4 tahun sekitar 10001600 kata dan pada usia 5 tahun 16002250 kata.

\section{Jenis-Jenis Kosakata}

Hurlock (1978:188) kosakata masa kanak-kanak diuraikan sebagai berikut :

a. Kosakata umum

Kosakata umum mencangkup kata benda, kata kerja, kata sifat, kata keterangan, kata perangkai dan kata ganti.

1) Kata benda termasuk kata yang pertama digunakan oleh anak, yang umumnya bersuku kata satu yang diambil dari celotehan yang disukai anak. Misalnya kata (baju, topi, kursi) kata-kata ini anak dapatkan dari apa yang anak sering dengar dan anak sering melihatnya.

2) Setelah anak mempelajari kata benda (nama orang dan benda yang ada disekitarnya), anak mulai mempelajari kata-kata baru yaitu kata kerja yang berkaitan dengan tindakan (beri, ambil, pegang). Misalnya ketika anak mendengar ajakan kata "pegang" maka anak akan merespon dengan memegang.

3) Pada umur 1.5 tahun anak mulai memunculkan kata sifat yang paling umum yang digunakan pada orang, makanan, atau minuman (bagus, baik, nakal, enak, panas, dingin, dsb)

4) Kata yang terakhir muncul pada anak yaitu kata perangkai dan kata ganti (ku, nya, kami, mereka). Misalnya anak mengatakan "mereka bermain bersama-sama" dalam kalimat ini terdapat kata mereka sebagai kata ganti. Namun kata ganti terakhir muncul dalam perkembangan kosa kata anak, hal ini dikarenakan anak masih bingung 
5) kapan penggunaan kata-kata ini digunakan.

b. Kosa kata khusus

Kosakata khusus berkaitan dengan warna, bilangan, waktu, mata uang, dan ucapan popular.

1) Pada usia 4 tahun anak mulai mengenal warna dasar. Anak mulai mengenal warna melalui proses belajar serta minat anak tentang warna itu sendiri.

2) Bilangan dikuasai anak secara berbeda, dalam skala intelegensi Stanford-binet, anak yang berusia 5 tahun sudah dapat menghitung 3 objek dan pada usia 6 tahun sudah cukup baik memahami kata bilangan (enam, satu, tujuh, sepuluh)

3) Kosakata waktu yang mendasar yang dipahami anak seperti (pagi, siang, malam) sedangkan untuk musim anak mulai mengetahuinya pada usia 6 dan 7 tahun.

4) Ukuran dan mata uang logam di ketahui dan dipahami anak pada usia 4 dan 5 tahun.

5) Pada usia 4-8 tahun anak sudah mulai menguasai kosakata popular dan digunakan untuk mengungkapkan emosi dan kebersamaan dengan teman sebayanya.

Adapun menurut Tarigan (1985) jenis kosakata dapat dikategorikan sebagai berikut :

\section{a. Kosakata Dasar}

Kosakata dasar bahasa sunda adalah kata yang tidak mungkin mudah berubah, di bawah ini termasuk dalam kosa kata bahasa sunda adalah sebagai berikut :

1) Istilah kekerabatan, misalnya ayah, ibu, nenek, kakek, paman, bibi, adik, kakak.

2) Nama-nama bagian tubuh, misalnya kepala, pundak, lutut, kaki, mata, hidung dsb.
3) Kata ganti (diri penunjuk), misalnya saya, kamu, dia, kami, itu, ini, situ, sana dsb.

4) Kata bilangan pokok, misalnya satu, dua, tiga, empat, lima dsb.

5) Kata kerja pokok, misalnya makan, minum, tidur, berbicara, melihat, mendengar menangkap dsb.

6) Kata keadaan pokok, misalnya suka, duka, senang, sakit, kotor, jauh, besar, kecil, tua, muda dsb.

7) Benda-benda universal, misalnya tanah, air, api, udara, bintang, matahari, tumbuhan dsb.

b. Kosakata aktif dan Pasif

Kosakata aktif adalah kosakata yang sering digunakan untuk berbicara atau menulis. Sedangkan kosakata pasif yakni kosakata yang jarang digunakan baik dalam menulis maupun berbicara (Soedjito, 1988:1).

\section{Kosakata Bahasa Sunda}

Pengembangan bahasa sunda untuk anak usia dini bertujuan untuk memperkenalkan ucapan kosakata dan ungkapan dalam bahasa sunda yang terjadi di lingkungan anak sehari-hari, memperkaya pengetahuan dan penggunaan berbagai bahasa, memperluas wawasan budaya anak, dan memperluas pengalaman anak dalam berbahasa.

Pada dasarnya pendidikan TK/RA mengacu pada dua aspek perkembangan dalam pembentukan perilaku melalui dua cara, yakni (1) pembiasaan dan (2) pengembangan kemampuan dasar. Melalui kedua pengembangan pembentukan kebiasaan dan kemampuan dasar tersebut, terutama kemampuan berbahasa Sunda, anak dapat tumbuh dan berkembang menjadi anak yang cageur, bageur, bener, pinter teu kabalinger, singer, tur pangger

Pada anak usia dini kosakata bahasa sunda tidak disajikan dengan mempelajari kecap salancar atau rajekan secara konsep, melainkan anak belajar kosakata mulai dari mengenal anggota tubuh, kemudian mengenal lingkungan anak sendiri. Kemudian anak belajar 
menggunakan bahasa sunda yang halus dan kasar, mengetahui kata benda, kata sifat, kata kerja dalam bahasa sunda, serta bagaimana penggunaannya dalam kehidupan.

Ruang lingkup pengembangan bahasa sunda untuk anak usia dini meliputi ngaregepkeun (mendengar), nyarita (berbicara), Pra maca (pra membaca), pra nulis (pra menulis). Adapun teknik yang digunakan biasanya berupa bermain, bernyanyi dan bercerita.

\section{Kognisi Dan Penguasaan Kosakata}

Dalam mengolah informasi, otak terspesialisasi dalam belahan kiri dan kanan. Kedua belahan otak (hemisfer) ini memiliki cara yang berbeda dalam meproses informasi. Umumnya, tiap-tiap orang memiliki spesialisasi, lebih cenderung memakai salah satu belahan. Ini dikenal dengan istilah dominasi otak. Dominasi otak ini memungkinkan seseorang dengan sangat mudah menjadi seorang analis (rasional) yang gampang mengolah data dan fakta melalui partikularisasi (bagian-bagian) atau menjadi seorang yang kreatif (intuitif) yang mengolah informasi secara lebih menyeluruh dan terpadu. Menurut jonathan ling \& Jonathan Catling Belahan otak kiri dipandang sebagai bagian otak yang mengendalikan fungsi-fungsi bahasa, yang meliputi produksi bahasa lisan dan tulisan dan pemahaman atas informasi verbal.

Hemisfer otak sebelah kiri berfungsi kritis bagi kemampuan bicara. Kemudian pendapat lain menyebutkan Bahasa bertempat di hemisfer otak sebelah kiri. Sedangkan kemampuan visualisasi tampaknya bayak menghuni hemisfer otak kanan (farah, 1988b, gazzaniga, 1985; zaidel, 1983). Hemisfer otak sebelah kiri cendrung memproses informasi secara analitik ( sekeping demi sekeping, biasanya secara urut), sedangkan hemisfer otak sebelah kanan cendrung memproses secara holistik (menyeluruh). Dari beberapa pendapat di atas dapat disimpulkan bahwa proses belajar bahasa baik kata hingga pada kosakata di proses melalui otak kiri anak yang memproses konsep-konsep tersebut menjadi sebuah pemahaman. Sedangkan otak kanan memproses informasi secara menyeluruh sehingga apabila kedua belahan otak kiri dan otak kanan tersebut bekerja sama dapat memungkinkan pemahaman konsep lebih mudah dicerna.

Anak-anak pada usia taman kanakkanak cendrung bersifat imajnatif dan kreatif. Hal ini dikarenakan pada usia tersebut merupakan tahap perkembangan otak kanan secara optimal. Otak kanan berfungsi terhadap pemikiran yang abstrak dengan penuh imajinasi. Maka dari itu menggabungkan otak kiri dan otak kanan dalam mempelajari bahasa khususnya kata dapat menjadi kegiatan yang menyenangkan bagi anak. Hal ini di karenakan konsep bahasa yang di proses otak kiri dibarengi dengan kegiatan imajinatif dan kreatif yang di proses otak kanan. Menurut Hernita (2013) kognitif dan musik merupakan proses pemikiran untuk mencapai pengetahuan yang berupa aktivitas mental seperti mengingat, mengkategorikan, mengsimbolkan, memecahkan masalah, menciptakan dan berfantasi. Adapun menurut Roger Sperry (1992) dalam Siagel (1999) bahwa neuron menjadi sirkuit jika ada rangsangan musik sehingga neuron yang terpisah-pisah itu mengintegrasikan dalam sirkuit otak, sehingga terjadi perpautan antara neuron otak kanan dan neuron otak kiri. Dengan demikian penggunaan musik dalam mempelajari bahasa dapat meberikan pengalaman yang menyenangka bagi anak dimana otak kanan dan otak kiri bekerjasama dalam proses penerimaan informasi.

\section{Pupuh Sunda}

Pupuh adalah puisi Jawa yang berasal dari sastra yang terikat oleh jumlah baris tiap bait, jumlah suku kata dalam tiap baris, suku kata terakhir dari tiap akhir baris, tempat atau saat pernafasan 
(pedotan) serta watek atau karakter (Soepandi, 1995: 168). Hal tersebut sesuai dengan pendapat Mariko (2007: 69) yang mengatakan bahwa pupuh ialah macapat yang merupakan pola lirik tembang yang diimport dari Jawa pada permulaan abad ke-17 pada saat kerajaan Mataram menjadikan wilayah Sunda sebagai wilayah mancanegara. Sedangkan menurut Caturwati (2007) pupuh adalah lagu Sunda atau Jawa dalam bentuk puisi yang terpola oleh guru lagu dan guru wilangan.

Berdasarkan beberapa pendapat tersebut, dapat disimpulkan bahwa pupuh ialah pola lirik yang terikat pada beberapa patokan (aturan) yang berupa guru wilangan, guru lagu, pedotan dan watek, yang di adopsi dari kesenian Jawa, yaitu macapat.

Pupuh memiliki arti bait atau pada, aturan, lagu, tembang, rangkaian bait yang memiliki pola yang sama, puisi jawa utama, puisi jawa lama, pola penyusunan syair atau rumpaka (Atiek Soepandi. 1985 : 3-4).

\section{Contoh Pupuh}

Contoh pupuh berikut merupakan pupuh yang sudah di aransemen rumpakanya atau lirik nya sehingga lebih proporsional untuk digunakan pada anak usia dini :

\section{PUPUH : ASMARANDANA \\ TEMA : KATA BENDA \\ RUMPAKA : Dr. Lili Suparli, M.Sn \\ Ngeduk sangu make cukil}

Mun ngakeul sok dina dulang

Nyeupan sangu dina sééng

Piring séndok jeungeun dahar

Mun nginum dina gelas

Mirun seuneu dina hawu

Nunda béas nya di goah

$\begin{array}{ll}\text { PUPUH } & : \text { BALAKBAK } \\ \text { TEMA } & : \text { HEWAN }\end{array}$

RUMPAKA : Atik S

Dina kandang aya maung nu rangéténg, nyangéréng

Monyét-monyét saré tibra semu ni'mat, nyangkéré

Kuda sébra kuda sébra awakna salur barelang, tétéjéh

\begin{tabular}{|c|c|}
\hline JPUH & : BALAKBAK \\
\hline TEMA & : KATA BENDA \\
\hline $\begin{array}{l}\text { UMPAKA } \\
\text { Sn }\end{array}$ & Muhamad Hasan Ansori, \\
\hline apakéan ur & pantes pisan, arahéng \\
\hline $\begin{array}{l}\text { véwéna } \\
\text { roncé }\end{array}$ & abaya salur kembang, \\
\hline
\end{tabular}

Lalakina lalakina make iket tur dipangsi, karasép

$\begin{array}{ll}\text { PUPUH } & \text { : BALAKBAK } \\ \text { TEMA } & : \text { ANGGOTA BADAN } \\ \text { RUMPAKA } & : \text { Asep Hendar Sutarya, } \\ \text { S.Sn. } & \end{array}$

Ieu cepil gunana keur ngadangungadangu

Ieu soca gunana eukeur ningal-ngareret

Ieu ambung ieu baham

aya lambey letah waos keur nyapek

\section{METODE PENELITIAN}

Metode yang digunakan dalam penelitian ini adalah penelitian tindakan kelas (PTK) model Kemmis \& MC Targgart yang terdiri dari 3 tahapan yaitu perencanaan, observasi \& pelaksanaan, refleksi.

Penelitian ini dilaksanakan di di TK Labschool UPI, yang beralamat di jl. Setiabudhi No. 229, Isola, Sukasari, kota Bandung. penelitian ini akan difokuskan pada anak kelompok B kelas Ubur-Ubur yang berjumlah 10 anak yang terdiri dari 4 anak laki-laki dan 6 anak perempuan.

Penelitian tindakan kelas ini dilaksanakan dalam dua siklus dimana setiap siklusnya terdiri dari tiga pertemuan.

Instrumen penelitian dalam penelitian ini, dibuat sendiri oleh peneliti mengacu pada teori serta lampiran keputusan 
gubernur mengenai standar kompetensi dan kompetensi dasar berbahasa sunda bagi TK/RA. Instrumen yang dibuat disesuaikan dengan tindakan yang akan diberikan kepada objek penelitian. Hal ini bertujuan untuk melihat kecepatan menambah kosakata.

Kecepatan menambah Kosakata yang dimaksud dalam penelitian ini adalah menambah kosakata dengan jumlah kata sebanyak 50 kata. Adapun kata yang dimaksud adalah kata anggota tubuh, benda di lingkungan sekitar, kata kerja dan nama hewan dengan berorientasi pada pupuh yang diberikan.

Pupuh yang dimaksud dalam penelitian ini adalah pupuh yang memiliki proporsi rumpaka yang sederhana dan mudah digunakan oleh anak. Pupuh yang digunakan di antaranya pupuh balakbak, kinanti, dan maskumambang. Hal ini bertujuan untuk memudahkan penggunaan bahasa sunda dalam meningkatkan jumlah kosakata bahasa sunda yag dapat anak gunakan dalam kehidupan sehari-hari.

Teknik pengumpulan data pada penelitian ini yaitu observasi (catatan lapangan dan daftar ceklis), wawancara, dan dokumentasi. Observasi merupakan teknik pengumpulan data yang dilakukan secara sistematis dan sengaja, yang dilakukan melalui pengamatan dan pencatatan gejala-gejala yang diselidiki. Observasi dilakukan untuk melihat dan mengamati aktivitas anak dalam kegiatan pembelajaran dan juga untuk mengamati kemampuan anak.

\section{TEMUAN DAN PEMBAHASAN}

\section{Kondisi Objektif Kecepatan Menambah Kosakata Bahasa Sunda Anak Melalui Kegiatan Ngawih Pupuh Sunda Pada Kelompok B Kelas Ubur-ubur TK Laboratorium Percontohan UPI}

Sebelum melakukan tindakan, peneliti melakukan kegiatan awal yang dilakukan pada tanggal 13 Februari dan 15 Februari 2018. Kegiatan ini bertujuan untuk mengetahui kondisi awal kosakata Bahasa Sunda anak sehingga peneliti dapat mengukur sejauh mana keberhasilan penelitian tindakan kelas ini. Kegiatan Pra siklus ini dilalaksanakan dengan peneliti berkolaborasi dengan guru kelas. Berdasarkan hasil data prasiklus menunjukan pencapaian Kecepatan Menambah Kosakata Bahasa Sunda Anak Pada Kelompok B Kelas Ubur-ubur Tk Laboratorium Percntohan UPI di gambarkan ke dalam diagram sebagai berikut :

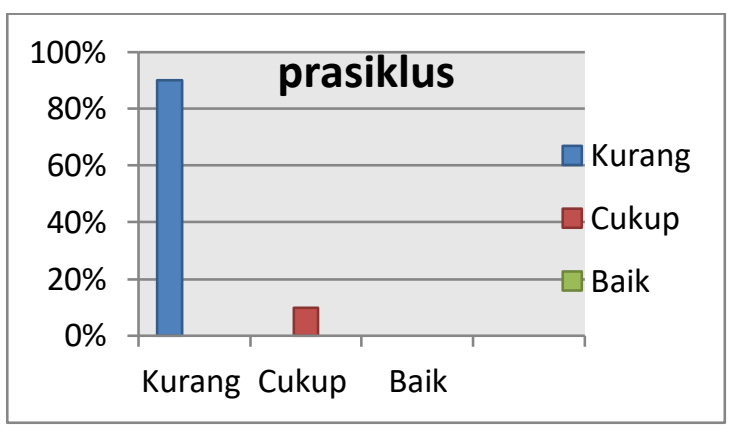

Grafik di atas menunjukan bahwa Kecepatan Menambah Kosakata Bahasa Sunda Anak Pada Kelompok B kelas Ubur-ubur belum mencapai perkembangan yang baik. Masih sangat banyak anak tergolong ke dalam kategori penguasaan kosakata yang kurang terbukti dengan data yang menunjukan $90 \%$ anak dalam kategori kurang (K), dan hanya $10 \%$ saja anak masuk ke dalam kategori cukup (C), namun belum ada anak yang masuk ke dalam kategori baik (B). berdasarkan data di atas peneliti bersama guru merencanakan untuk melanjutkan tindakan sebagai upaya menambah kosakata bahasa sunda anak.

2. Pelaksanaan Kegiatan Ngawih Pupuh Sunda Dalam Menambah Kosakata Bahasa Sunda Anak Pada Kelompok B Kelas UburUbur Tk Laboratoriu Percontohan UPI

Pelaksanaan kegiatan ngawih pupuh sunda dalan menambah kosakata bahasa sunda anak sunda pada kelompok B kelas 
ubur-ubur di TK Laboratorium Percontohan UPI dilaksanakan denga dua siklus dimana setiap siklusnya terdiri dari dua tindakan. Siklus I tindakan I dilaksanakan pada Selasa, 27 Februari 2018 dengan kegiatan ngawih pupuh balakbak bertemaka hewan . siklus I tindakan II dilaksanakan pada Jumat 2 Maret 2018 dengan pupuh balakbak bertemakan pakaian (kata benda). Siklus II tindakan I dilaksanakan pada kamis 8 Maret 2018 dengan pupuh balakbak bertemakan aggota tubuh dan siklus II tindakan II dilaksanakan pada Rabu 14 Maret 2018 dengan pupuh kinanti yag bertemakan kata benda.

3. Hasil Kecepatan Menambah Kosakata Bahasa Sunda Anak Melalui Kegiatan Ngawih Pupuh Sunda Pada Kelompok B Kelas Ubur-Ubur Di TK Laboratorium Percontohan UPI

Setelah melaksanaka kegiatan ngawih pupuh sunda di TK Laboratorium Percontohan UPI kosakata anak mulai terlihat adanya penambahan. Hal tersebut ditunjukan dari data yang diperoleh peneliti pada saat proses kegiatan penelitian berlangsung. hasil observasi terhadap kecepatan menambah kosakata Bahasa Sunda melalui kegiatan ngawih pupuh sunda pada setiap siklus sebagai berikut :

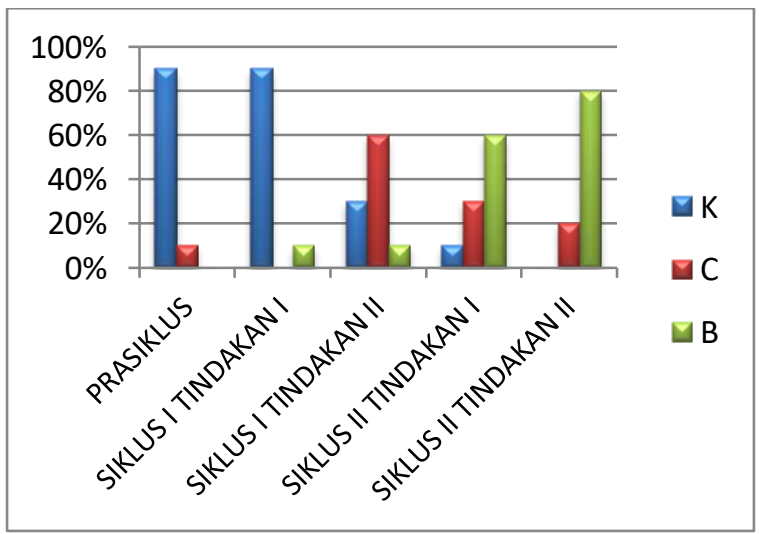

Berdasarkan diagram tersebut terlihat peningkatan kecepatan menambah kosakata Bahasa Sunda anak pada setiap siklusnya. Hasil grafik di atas merupakan hasil pemaparan dari presentase setiap kategori masing-masing tindakan. Pada prasiklus menunjukan kategori (K) $90 \%$, kategori cukup (C) 10\%. Pada siklus I tindakan I masih terlihat kategori sama termasuk ke dalam kategori kurang (K) 90\%, kategori cukup (B) 10\%, namun dari segi skor mengalami peningkatan. Pada siklis I tindakan II mengalami penurunan dan peningkatan pada setiap kategorinya. Pada kategri kurang (K) dari 90\% menurun menjadi $30 \%$, pada kategori cukup (C) mengalami peningkatan dari $10 \%$ menjadi $60 \%$ dan kategori baik (B) $10 \%$.

Pada siklus II terjadi peningkatan yang cukup signifikan serta penurunan pada kategori Kurang (K) dan kategri Cukup (C). Pada kategori kurang (K) mengalami penurunan dari $10 \%$ menjadi $0 \%$, pada kategori Cukup (C) mengalami penurunan dari $30 \%$ menjadi $20 \%$ penurunan terjadi sebanyak $10 \%$, kemudian pada kategori baik (B) mengalami peningkatan sebanyak $20 \%$ dari $60 \%$ menjadi $80 \%$. Pada akir disiklus yang di lihat dari awal atau prasiklus peningkatan terjadi sebanyak $70 \%$.

\section{Pembahasan}

1. Kondisi Objektif Kecepatan Menambah Kosakata Bahasa Sunda Anak Pada Kelompok B Kelas Ubur-Ubur Di TK Laboratorium Percontohan UPI

Berdasarkan hasil observasi awal, kondisi kosakata Bahasa Sunda anak belum memiliki kosakata yang beragam. Pada saat kegiatan berlangsung sebagian besar anak belum memahami Bahasa Sunda, belum dapat menyebutkan kata Bahasa Sunda yang diketahui, Kemudian anak belum mampu mengulang rumpaka pupuh yang sudah di dengarkan, anak belum memahami arti dari rumpaka pupuh dari kegiatan pupuh yang sudah dilakukan.

Kosakata Bahasa Sunda anak pada kelompok B Kelas Ubur-Ubur Di TK Laboratorium Percontohan UPI berdasarkan hasil observasi awal prasiklus sebelum peneliti dan guru melakukan 
kegiatan ngawih pupuh sunda dari 10 anak yang diamati menunjukan $10 \%$ anak mendapatkan kategori cukup dan 90\% anak mendapatkan kategori kurang. Hal ini terlihat dari 50 item pernyataan yang peneliti sajikan hanya 1 anak yang berada dalam kategori nilai skor yang cukup sedangkan 9 anak lainnya memperoleh nilai skor dengan kategori kurang.

Adapun hal yang menyebabkan kondisi awal kosakata Bahasa Sunda anak kurang beragam adalah orangtua yang terbiasa berkomunikasi dengan Bahasa Indonesia dengan mengesampingkan bahasa daerahnya yaitu Bahasa Sunda. Selain itu juga kurang optimalnya pelaksaan program Rebo nyunda di TK. Program ini hanya dilaksanakan dengan atribut penggunaan baju kebaya dan pangsi sebagai ciri rebo nyunda serta kegiatan silat di hari rabu namun pada prosesnya tidak di gunakan Bahasa Sunda sebagai bahasa pengantar pembelajaran di sekolah. Sehingga anak-anak mengakui dirinya orang Bandung tapi tidak mau berbahasa Sunda karena dianggap hal yang asing.

2. Pelaksanaan Kegiatan Nagwih Pupuh Sunda Untuk Menambah Kosakata Bahasa Sunda Anak Kelompok B Kelas Ubur-Ubur Di TK Laboratorium Percontohan UPI

Pelaksanaan siklus I tindakan I dilaksanakan pada Selasa 27 Februari 2018. Sebelum melaksanakan kegitan guru terlebih dahulu mengatur posisi duduk anak dengan kocokan nomor, selanjutnya kegiatan dilanjutkan dengan berdoa, saling menyapa dan bernyanyi. Guru mengenalkan Pupuh dan menjelaskannya dengan menggunakan Bahasa Sunda. Pupuh yang disampaikan adalah pupuh balakbak yang bertemakan hewan. Selanjutnya anak bersama guru menyanyikan pupuh dengan berulangulang. Setelah selesai guru mengajaka anak bermain kuis. Kuis ini merupakan pertanyaan yang mencangkup kata-kata dalam rumpaka pupuh yang sudah di lakukan sebelumnya.
Pada pelaksanaan siklus I tindakan I dilaksanakan pada Jumat 2 Maret 2018. Kegiatan awal sebelum memasuki kegitan pupuh sama dengan kegiatan sebelumnya yaitu mengatur posisi duduk anak, kemudian berdoa bersama, saling menyapa dan bernyanyi. Guru mengulas kembali pupuh yang sebelumnya sudah anak nyanyikan dan bertnya jawab soal arti rumpaka pupuh nya. Selanjtnya guru mengenalkan pupuh baru yaitu pupuh balakbak dengan tema benda yaitu pakaian. Seperti biasa guru menjelaskan arti rumpakanya dan anak-anak mengikuti menyebutkan rumpakanya. Kemudian anak-anak menyanyikan pupuh dengan guru. Pada kegiatan penutup anak-anak diajak bermain kuis kembali dengan pertanyaan yang mencangkup kata dari rumpakapupuh.

Pada siklus I tindakan I ditemukan kelemahan yaitu dalam mengkondisikan anak-anak guru kurang sigap, kemudian guru yang belum hafal dengan teks rumpaka pupuh. Adapun perbaikan yang harus dilakukan dalam tindakan selanjutnya adalah mengkondisikan anak dengan posisi duduk yang tepat sehingga tidak ada anak yang mengobrol mengganggu konsentrasi anak lain pada kegiatan. Selanjutnya guru berlatih kembali dan menghafalkan teks rumpaka pupuh agar tidak terpaku pada teks. Maka dari itu peneliti dan guru melakukan tindakan selanjutnya.

Pada siklus I tindakan II mulai terlihat bahwa kegiatan ngawih pupuh sunda memberikan kecepatan menambah terhadap penguasaan kosakata Bahasa Sunda anak. Contohnya anak sudah mulai menggunakan Bahasa Sunda ketika berbicara seperti "duka teu terang" "sanes eta". Selain itu juga anak-anak berhitung menggunakan Bahasa Sunda, mengikuti ucapan guru dalam menggunakan Bahasa Sunda. Anak mulai mengenal nama hewan dengan Bahasa Sunda. Kemudian perbaikan yang harus dilakukan dalam tindakan selanjutnya adalah guru lebih memahami arti dari rumpaka pupuh 
sehingga dalam menyampaikannya kepada anak lebih mudah. Kemudian guru lebih menstimulasi anak agar lebih berinisiatif mengucapkan kata-kata dan kalimat dalam Bahasa Sunda, serta mengkondisikan anak sehingga tidak terlihat lagi anak yang mengganggu teman ketika kegiatan. Untuk itu peneliti dan guru harus dapat memperbaiki kelemahan pada tindakan II ini dan meningkatkan penguasaan kosakata Bahasa Sunda pada tindakan selanjutnya.

Pelaksanaan Siklus II tindakan I dilaksanakan pada Kamis 8 Maret 2018. Sebelum memulai kegiatan terlebih dahulu guru mengatur posisi duduk anak dengan mengocok nomor. Selanjutnya berdoa sebelum belajar, menyapa dan salam kemudian bernyanyi. Guru selanjutnya menggulas kembali ingatan anak mengenai pupuh yang sudah di nyanyikan bersama sebelumnya. Kemudian guru menjelaskan pupuh baru dengan tema anggota tubuh kepada anak-anak. Guru menjelaskan arti rumpaka dengan memegang objek sehingga anak melakukan kegiatan ngawih dengan gerkan. Setelah itu guru menyanyikan rumpaka pupuh dengan di ikuti oleh anak-anak. Selanjutnya di lakukan kuis dimana pertanyaan yang disampaikan guru terkait dengan kata-kata dalam rumpaka. Pada siklus II tindakan I ini sudah mulai terlihat penambahan kosakata Bahasa Sunda anak. Anak-anak mulai terbiasa mengucapkan kata-kata dalam rumpaka, anak-anak mampu mengulang kembali kalimat dalam rumpaka, anak mampu menjawab arti dari rumpaka pupuh. Perbaikan yang harus dilakukan pada tindakan selanjutnya adalah guru memotivasi anak agar anak jauh lebih ekspresif dalam kegiatan ngawih pupuh, guru memberikan rewards pada anak sehingga anak terpacu untuk lebih baik dalam kegiatan ngawih pupuh serta memahami arti dari rumpakanya. Dari siklus II tindakan I ini peneliti dan guru belum puas dengan hasil kecepatan menambah kosakata hal ini dikarenakan belum mencapainya target harapan kecepatan menambah kosakata anak. Maka peneliti dan guru memutuskan melanjutkan tindakan selanjutnya.

Siklus II tindakan II ini dilaksanakan pada Rabu 14 Maret 2018, seperti biasanya sebelum memulai kegiatan di kelas guru mengatur posisi duduk anak, kemudian berdoa, menyapa dan salam kemudian bernyanyi. Guru mengingatkan anak mengenai pupuh-pupuh sebelumnya yang sudah dinyanyikan. Guru mencoba mengajak anak menyanyikan kembali pupuh sebelumnya. Kemudian guru menyampaikan pupuh baru yaitu pupuh kinanti dengan tema benda. Guru menjelaskan arti rumpakanya dan kemudian menyanyikan nya bersama anak-anak. Setelah kegiatan pupuh selesai anak-anak diberi kuis oleh guru mengenai arti rumpaka yang sudah diyanyikan hari ini dan sebelumnya. Pada siklus II tindakan II ini anak-anak sudah antusias dan ekspresif dalam melakukan kegiatan anak mulai terihat jauh lebih menikmati kata-kata baru berbahasa sunda yang di dengarnya. Anak tidak malu ketika disuruh guru menyanyikan sendiri di depan kelas. Selain itu anak mengulang kalimat pada rumpakas erta mengaplikasikannya pada saat kegiatan pembelajaran. Contohnya saja anak menyebutkan "dangukeun", "calik" dsb. Pada siklus II tindakan II ini kecepatan menambah kosakata Bahasa sunda anak sudah mengalami peningkatan yang memenuhi indikator keberhasilan. Sehingga peneliti dan guru merasa tindakan diarasa sudah cukup dan dihentikan.

\section{Kecepatan Menambah Kosakata Bahasa Sunda Anak Kelompok B Kelas Ubur-Ubur Tk Laboratorium percontohan UPI Setelah Dilaksanakannya Kegiatan Ngawih Pupuh Sunda.}

Berdasarkan hasil penelitian yang telah dilaksanakan menunjukan adanya peningkatan yang cukup baik pada penambahan kosakata bahasa sunda anak hal ini terliha dari hasil beberapa tindakan 
pada setiap siklusnya. Penambahan terlihat dalam kategori anak prasiklus sama sekali tidak ada namun hanya ada kategori cukup dan baik. Pada siklus I tindakan I kategori masih sama namun penambahan pada skor sangat terlihat cukup baik. Pada siklus I tindakan II mulai muncul kategori baik $10 \%$ kemudian pada siklus II tindakan I kategori baik meningkat menjadi $60 \%$ hasil ini sangat meningkat tajam dikarenakan anak-anak yang berada pada kategori cukup mengalami peningkatan hingga mampu mencapai kategori baik. Dan pada siklus II tindakan II kategori baik $80 \%$ ini meningkat $20 \%$ dari hasil tindakan sebelumnya.

Pada penelitian hasil kecepatan penambahan kosakata bahasa sunda anak pada prasiklus dan siklus I tindakan I kategori kurang 90\% dan anak dalam kategori baik $10 \%$, namun terlihat dari hasil skor prasiklus anak-anak paada kategori kurang berada pada skor 50-60 sedangkan kategori cukup mencapai skor 90. Skor ini meningkat pada siklus I tindakan I yaitu anak-anak pada kategori kurang berada pada skor 59-80 sedangkan pada kategori cukup anak mendapatkan skor 136.

Pada siklus I terjadi peningkatan dan penurunan pada setiap kategorinya. Kategori kurang (K) menurun sebanyak $60 \%$ dari $90 \%$ menjadi $30 \%$, dalam kategori cukup (C) menjadi 60\%, dan dalam kategori baik (B) meningkat $10 \%$ dari $0 \%$ menjadi $10 \%$.

Pada akhir siklus II terjadi peningkatan dan penurunan kategori yang cukup signifikan. Kategori kurang (K) pada akhir siklus menjadi 0\%, kategori cukup (C) mengalami penurunan sebanyak $10 \%$ dari $30 \%$ menjadi $20 \%$, dalam kategori baik (B) mengalami peningkatan sebanyak $20 \%$ dari $60 \%$ menjadi $80 \%$. Pada siklus II tindakan I ini anak berada pada kategori cukup berada pada skor 80-116 dan anak pada kategori baik berada pada skor 117143. Dari hasil skor yang didapatkan oleh anak menunjukan bahwa adanya kecepatan yang signifikan dari kegitan ngawih pupuh sunda terhadap penambahan kosakata bahasa sunda anak.

Hal ini sesuai dengan Dale.et dalam Tarigan (1985) bahwa anak-anak mempelajari kosakata dari apa yang anak dengar dari orang yeng lebih tua, teman sebayanya, dari berbagai media masa, dari lagu dsb, selanjutnya anak juga mempelajari kosakata dari apa yang alami sendiri seperti menggucapkan benda karna mereka melihat dan menyentuh bendanya. Dengan kegiatan ngawih pupuh sunda yang dibimbing guru, dengan di iringi gerak menyentuh objek serta mengulang kegiatan nagwih terus menerus anak-anak akan mulai terbiasa dengan kosakata bahasa sunda yang baru bagi dirinya.

Selain itu sesuai dengan Surat Keputusan Gubernur Jawa Barat Nomor 423.5/Kep.674-Disdik/2006 Tanggal 26 Juli 2006 Mengenai Kompetensi Berbahasa Sunda Untuk Taman KanakKanak Dan RA salah satu kompetensi dasar berbahasa sunda bagi anak usia dini adalah memperkaya dan mengucapkan kosakata sehari-hari yang berkaitan dengan ligkungan sekitar serta menyanyikan rumpaka kawih sunda dengan benar. Hasil penelitian menunjukan bahwa kegiatan nagwih pupuh sunda dapat menambah kosakata bahasa sunda anak Kelompok B Kelas Ubur-Ubur Di TK Laboratorium Percontohan UPI.

Hal ini juga dipengarui oleh berkembag pesatnya otak kana anak usia dini sehingga pemahaman anak mengenai konsep kosakata yang diproses olah otak kiri di gabungka dengan metode bernyanyi pupuh dimana prosesnya menggunakan otak kana sehingga kegiatan memahami kosakata jauh lebih menyenangkan dan mudah di pahami anak ini sesuai dengan pendapat Roger Sperry (1992) dalam Siagel (1999) bahwa penggunaan musik dalam mempelajari bahasa dapat meberikan pengalaman yang menyenangka bagi anak dimana otak kanan dan otak kiri bekerjasama dalam proses penerimaan informasi. 


\section{SIMPULAN DAN REKOMDASI}

A. Simpulan

Berdasakan hasilpenelitian

tindakan kelas tentang Keceptan

Menambah Kosakata Bahasa

Sunda Melalui Kegiatan Ngawih

Pupuh Sunda anak pada Kelompok

B Kelas Ubur-Ubur Di TK

Laboratorium Percontohan UPI

dapat disimpulkan sebagai berikut :

1. Kosa kata Bahasa Sunda pada anak Kelompok B Kelas Ubur-Ubur Di TK Laboratorium Percontohan UPI sebelum dilakukannya kegiatan nagwih pupuh sunda masih belum beragam. Hal tersebut dikarenakan anak-anak tidak terbiasa menggunakan Bahasa Sunda baik di rumah maupun di sekolah, kegiatan di sekolah jarang sekali menggunakan Bahasa Sunda kecuali pada saat menyapa anak. Selain itu kurang optimalnya implementasi rebo nyunda di taman kanak-kanak menjadi salah satu penyebabnya. Karena di taman kanak-kanak biasanya rebo nyunda hanya di laksanakan dengan atribut memakai pakaian adat sunda serta kegiatan silat saja tapi tidak dibarengi dengan pengunaan Bahasa Sundanya. Sebagian besar anak belum mampu menyebutkan kata yang dikenal dalam Bahasa Sunda, belum mampu mengikuti guru menyanyikan rumpaka, belum mampu mengulang kembali rumpaka.

2. Pelaksanaan kegiatan ngawih pupuh sunda dilaksanakan sebanyak dua siklus yaitu siklus I tindakan I, siklus I tindakan II, siklus II tindakan I, siklus II tindakan II. Dalam pelaksanaan kegiatan terjadi perubahan dalam pengunaan Bahasa Sunda dalam kegiatan pembelajaran. Hal tersebut dipengaru oleh guru yang menggunakan Bahasa Sunda dalam kegiatan dikelas, meotivasi anak agar anak mau menggunakan Bahasa Sunda, sehingga anak menjadi suka berBahasa Sunda, lebih tertarik ngawih pupuh dengan gerakan yang atraktif dan antusias dalam mengikuti kegiatan.

3. Kecepatan menambah kosa kata Bahasa Sunda anak Kelompok B Kelas Ubur-Ubur Di TK Laboratorium Percontohan UPI setelah dilakukan kegiatan gawih pupuh sunda mengalami penambahan. Hal ini dapat dilihat drai hasil pencapaian indikator pada prasiklus hingga akhir siklus II. Dengan kegiatan ini penambahan mencapai $80 \%$. Hal ini dapat dilihat dari anak mampu menyimak perkataan orang lain dalam Bahasa Sunda, mengikuti menyanyikan rumpaka kawih (pupuh), menyebutkan kata yang dikenal dalam Bahasa Sunda, mengulang kata dan kalimat sederhana dalam Bahasa Sunda. Bahkan anak menjadi senang melakukan kegiatan nagwih pupuh sunda, anak-anak antusias dan ekspresif dalam kegiatan. Selain itu anak jadi mau menggunakan Bahasa Sunda. Maka dapat disimpulkan bahwa kegiatan nagwih pupuh sunda dapat menambah kosakata Bahasa Sunda anak anak Kelompok B Kelas Ubur-Ubur Di TK Laboratorium Percontohan UPI.

\section{Rekomendasi}

1. Kepala Sekolah TK

a. Mengoptimalkan program Rebo nyunda dengan menerapkan pengunaan bahasa sunda di hari Rabu bagi Guru, anak, dan orangtua di sekolah.

b. Memfasilitasi media penunjang untuk berbahasa sunda sehingga anak mau menggunakan bahasa sunda.

c. Membuat program nyunda disekolah yang menyenangkan bagi anak.

\section{Guru}


a. Diharapkan guru menggunakan bahasa sunda sebagai bahasa pengantar proses pembelajaran pada hari Rabu sebagai salah satu program rebo nyunda .

b. Penambahankosakata bahasa sunda anak dapat ditingkatkan dengan menggunakan kegiatan ngawih pupuh sunda yang sesuai dengan kompetensi dasar berbahasa sunda. Diharkan dengan kegiatan nagwih bahasa sunda dianggap lebih menyenangkan bagia anak.

c. Guru berinisiatif untuk mengenalkan dan meningkatkan bahasa sunda anak sebagai salah satu persiapan anak melanjutkan sekolah kejenjang berikutnya dimana terdapat mata pelajaran bahasa sunda.

d. Melalukan inovasi kegiatan sebagai salah satu kegiatan penunjang berbahasa sunda bagi anak.

\section{Orangtua}

Orangtua sebagai pendidik pertama dan paling utama bagi anak sebaiknya mengenalkan bahasa daerahnya khususnya jawa barat bahasa sunda sebagai salah satu bahasa untuk berkomunikasi. Hal ini bertujuan agar anak mengenal bahasa ibunya mengenal bahasa daerahnya. Selain itu hal ini juga bertujuan agar anak menjadi salah satu generasi yang melestarikan budaya daerahnya. Diharapkan orangtua menggunakan bahasa sunda kepada anak sesekali agar anak terbiasa mengunakannya.

4. Peneliti selanjutnya

Untuk peneliti selanjutnya kegiatan ngawih pupuh sunda dapat digunakan sebagai salah satu metode pembelajaran bahasa sunda. Hal yang harus di perhatikan yaitu sebaiknya berkolaborasi dengan orang yang ahli di bidangnya sehingga lebih maksimal dalam pelaksanaanya. Selanjutnya memperluas cakupan kosa kata sehingga penambahan kosakata anak akan semakin kaya. Kemudian menggunakan media penunjang yang lebih menarik, salah satunya dengan menggunakan media wayang golek atau digabungkan dengan kegiatan kaulinan barudak sunda.

\section{DAFTAR PUSTAKA}

Hendarsyah. (Wawancara Pada 15 April 2017)

Hurlock, E. B. (2007). Psikologi Perkembangan. Jakarta : Erlangga

Keraf,G. (2001). Diksi Dan Gaya Bahasa. Jakarta : Gramedia Pustaka Utama

Lampiran Surat Keputusan Gubernur Jawa Barat Nomor: 423.5/Kep.674Disdik/2006 Tanggal 25 Juli 2006 Tentang Standar Kompetensi Dan Kompetensi Dasar Serta Panduan Penyusunan Kutikulum Tingkat Satuan Pendidikan Mata Pelajaran Bahasa Dan Sastra Sunda

Ling, J., Catling, J. (2012) Psikologi Kognitif . Jakarta : Erlangga

Nurbiana, Dhieni (2015). Metode Perkembangan Bahasa. Jakarta : Universitas Terbuka

Sodjito. (1988) Kalimat Efektif. Bandung : Remaja Rosdakarya

Soepandi, Atik (1985). Lagu Pupuh Pengetahuan Dan Notasinya. Bandung: Pustaka Buana

Suhartono, (2005). Pengembangan Keterampilan Bicara Anak Usia Dini. Jakarta : Depdiknas

Suparli, Lili (Wawancara Pada 14 Maret 2017)

Tarigan, Henry Guntur (1989). Pengajaran Kosakata. Bandung : Penerbit Angkasa

Hernita (2013). Peran Otak Kanan Pada Anak Usia Taman Kanak-Kanak. Hernitapd.Wordpress Diakses Pada 26 April 2018

Krismas M (2005). Kontribusi Permainan Flash Card Dalam Meningkatkan Kemampuan Kosakata Anak Tuna 
Grahita Ringan Di Slb-C Purna Asih, Skripsi, Bandung. Fip Upi

Kurniawati, Y. (2009). "Tingkat Penguasaan Bahasa Sunda Anak Tk Di Kabupaten Bandung". Bandung. Upi

Sobarna, C. (2007). "Pemeliharaan Bahasa Ibu: Sebuah Upaya Memperkukuh Jati Diri”. Makalah Hari Bahasa Ibu Internasional, Universitas Padjadjaran, Bandung

Yadnya,B.P. (2003). "Revitalisasi Bahasa Daerah (Bali) Di Tengah Persaingan Bahasa Nasional, Bahasa Daerah Dan Asing Untuk Memperkukuh Ketahanan Budaya". Makalah Kongres Bahasa Indonesia Viii, Jakarta

Peraturan Daerah Provinsi Jawa Barat N0. 5 Tahun 2003 Tentang Pemeliharaan Bahasa, Sastra dan Aksara Daerah, yang menetapkan Bahasa Daerah, antara lain Bahasa Sunda, harus di ajarkan mulai dari Taman KanakKanak (TK) sampai Sekolah Menengah Atas (SMA) di Jawa Barat.

Siegel, G. Joel dan Jae K. Shim. Kamus Istilah Akuntansi. Jakarta: PT: Elex Media Komputindo

Peraturan Daerah Provinsi Jawa Barat Sasaki, Mariko. 2007. Laras Pada Karawitan Sunda. Yogyakarta: P4ST UPI

Caturwati, Endang. 2007. Tari di Tatar Sunda. Bandung: Sunan Ambu Press- STSI Bandung 